Structures and Buildings

Volume 171 Issue SB1

Structural assessment of composite seam-welded rectangular hollow columns Castanheira, de Lima, da Silva Vellasco and da Nóbrega Tavares
Proceedings of the Institution of Civil Engineers Structures and Buildings 171 January 2018 Issue SB 1 Pages 64-73 https://doi.org/10.1680/jstbu.16.00190 Paper 1600190 ite Qe

\title{
Structural assessment of composite seam-welded rectangular hollow columns
}

Deborah Souza Castanheira BSc, MSc

PhD Student, PGECIV - Civil Engineering Post Graduate Program,

UERJ - State University of Rio de Janeiro, Rio de Janeiro, Brazil

Luciano Rodrigues Ornelas de Lima BSC, MSC, DSC

Associate Professor, Structural Engineering Department, UERJ - State

University of Rio de Janeiro, Rio de Janeiro, Brazil (corresponding author:

lucianolimauerj@gmail.com; lucianolima@uerj.br)

\author{
Pedro Colmar Gonçalves da Silva Vellasco BSC, MSc, \\ PhD, DIC \\ Professor, Structural Engineering Department, UERJ - State University of \\ Rio de Janeiro, Rio de Janeiro, Brazil \\ Maria Elizabeth da Nóbrega Tavares BSc, MSc, DSC \\ Associate Professor, Structural Engineering Department, UERJ - State \\ University of Rio de Janeiro, Rio de Janeiro, Brazil
}

Structural elements made of seam-welded hollow sections are considerably less expensive than their seamless equivalents. This is a strong incentive for their use, but the current steel design standards still contain recommendations for seam-welded hollow sections based on test results performed with sections produced using outdated steel grades and fabrication processes. These design procedures are even more conservative when applied to composite tubular seam-welded elements. This paper presents an experimental campaign performed to investigate the structural behaviour of steel- and concrete-filled composite columns made with seam-welded rectangular hollow profiles. The experiments involved columns with only steel sections, concrete-filled and concrete-filled plus additional reinforcing bars. The main aim of the tests was to identify the contribution of each component in the overall structural response. The results enable an evaluation of the design recommendations present in Eurocode 4 aiming to determine less conservative buckling curves to be used for the investigated composite columns made of seam-welded rectangular hollow sections.

\section{Notation}

$A_{\text {a }}$

$A_{\mathrm{c}}$

$A_{\mathrm{s}}$

$E$

$E_{\mathrm{cm}}$

$f_{\mathrm{cd}}$

$f_{\mathrm{ck}}$

$f_{\mathrm{s}}$

$f_{\text {sd }}$

$f_{\mathrm{u}}$

$f_{\mathrm{y}}$

$f_{\text {yd }}$

$N_{\text {b,Rd }}$

$N_{\text {EC4 }}$

$N_{\text {exp }}$

$N_{\text {pl,Rd }}$

$\alpha_{\mathrm{cc}}$

$\bar{\lambda}$

$\chi$

\section{Introduction}

Novel building construction strategies and techniques are constantly being developed to achieve greater heights of structures with economic efficiency. One of the most popular solutions brings together reinforced concrete and structural steel, usually known as composite structures.

These composite structures have many advantages, such as: minimising the corrosion of the concrete reinforcing steel bars (in steel hollow sections filled with concrete); protection of the structural steel profile when it is encased in concrete; better response to fire conditions; and reduction of the column crosssection, among others. Many composite columns were initially used to enhance the structure's fire resistance; however, the development of high-strength steel and concretes, alongside the pressing need to construct higher buildings, have together boosted the adoption of composite columns design (Calado and Santos, 2013).

Recent studies (Silva et al., 2016; Tenchini et al., 2014) have highlighted the advantages of using composite columns in moment-resisting frames ('dual steel') characterised by the combined use of high-strength steel (HSS) in non-dissipative members and mild carbon steel (MCS) in dissipative zones, especially for inducing the seismic response of multi-storey buildings to be controlled by overall ductile mechanism responses.

When composite seam-welded columns are considered, reports presented in the literature highlight the need for a better understanding of their global behaviour and the influence of effects such as residual stresses and concrete confinement.

Schneider (1998) presented an experimental and analytical study of short, concrete-filled steel tube columns concentrically loaded in compression up to failure. This study involved 14 compressive axial tests of circular, square and rectangular composite columns. All steel tubes were made of cold-formed carbon steel with a specified yield strength of $317 \mathrm{MPa}$. All tubes were seam welded and annealed to relieve residual stresses. The main conclusions were: the square and rectangular 
tube walls did not show a significant concrete nucleus confinement after the yield load of the composite column and the AISC specification (ANSI/AISC, 2010) provided a conservative prediction for the axial strength of the composite columns.

Han (2002) investigated the behaviour of 24 concrete-filled rectangular hollow section (RHS) stub columns subjected to axial compression. The tubes were all manufactured from mild steel sheet, with four plates cut from the sheet, tack welded into a rectangular shape and then welded with a single bevel butt weld at the corners. On these tests, the typical failure mode was local (outward folding) failure mechanism. The section capacities predicted using the Eurocode 4 (BSI, 2004) design methods were compared with the stub column test results. The results predicted by Eurocode 4 were $10 \%$ lower than the tests with a mean value of 0.879 and a coefficient of variation (COV) of 0.0991.

Sakino et al. (2004) tested 114 hollow and concrete-filled steel tubular (CFT) short column specimens under axial compression. The main test parameters were: $(a)$ tube shape, (b) tube tensile strength, $(c)$ tube diameter-to-thickness ratio and $(d)$ concrete strength. The circular steel tubes were cold formed from a flat plate by press bending and seam welding. The square steel tubes were fabricated by welding together two pieces of channel section, which were cold formed from a flat plate. For circular composite columns, the authors concluded that the design formula in the Architectural Institute of Japan recommendations (AIJ, 1997) predicts with good accuracy the axial load capacity. However, for square composite columns, the cited design code led to a slightly conservative value for columns with small $\mathrm{B} / \mathrm{t}$ ratio where $\mathrm{B}$ and $\mathrm{t}$ are the width and the thickness of the square cross-section, respectively. According to the authors, the main reason for this difference can be associated with strain hardening effects in the steel tubes.

Nardin and El Debs (2006) reported an experimental study of CFT columns. Six short columns subjected to concentric load were tested. Columns of square (CFTS), circular (CFTC) and rectangular (CFTR) cross-sections with two steel tube thicknesses were tested. The square tubes for CFTS and the rectangular tubes for CFTR were constructed by seam welding two U-shaped, cold-formed steel plates. The circular tubes for CFTC were hot-rolled structural steel sections. The experimental results showed that the ductility of high-strength concrete increased when confined by a steel tube, but the load-carrying capacity remained the same. The confinement effect did not raise the capacity of the columns because the axial strain of the high-strength concrete core was significantly not mobilised up to the column ultimate load. A model to predict the load against strain behaviour was proposed and the prepeak and post-peak behaviour of concrete-filled steel columns when axially loaded could be predicted from the response of the steel tube and concrete core. As a result, Eurocode 4 and
American Institute of Steel Construction (AISC) underestimate the axial load capacity of the specimens with circular crosssection where the highest difference reached was $28 \%$.

Han et al. (2008) produced 32 stub composite columns experiments with end plates, divided into circular and square sections, submitted to axial compression. The tubes were all manufactured from mild steel sheet $(2.83 \mathrm{~mm}$ thick with a yielding strength of $362.9 \mathrm{MPa}$ ), with the plate being cut from the sheet, tack welded into a circular or square shape and then welded with a single bevel butt weld. The measured compressive cube strength $\left(f_{\text {cu }}\right)$ was $74.3 \mathrm{MPa}$. The columns exhibited a ductile response during the tests. The resistance was controlled by the steel tube and, as the endplates' thickness increased, the steel tube ends deformation, restrained by a thick endplate, enhanced the concrete confinement effects.

Oliveira et al. (2009) performed an experimental analysis of the confinement effects in steel-concrete composite columns centred on two parameters: concrete compressive strength and column slenderness. Sixteen CFT columns with circular crosssection were tested under axial loading. The tested columns were filled by concrete with compressive strengths of 30,60 , 80 and $100 \mathrm{MPa}$, and had length/diameter ratios of 3, 5, 7 and 10. According to the results, Eurocode 4 (BSI, 2004) and CAN/CSA (2001) presented the lowest differences between the predicted and the experimental ultimate load results, $2 \cdot 4 \%$ and $2 \cdot 3 \%$ on average.

Recently, Han et al. (2014) presented some developments and advanced applications of CFT structures focusing on the member behaviour. The authors showed a comparison of the measured results between a circular steel (S) stub column, a reinforced-concrete (RC) stub column and a concrete-filled steel tubular (CFST) stub column without steel reinforcement. As expected, the ultimate strength for a concrete-filled steel tube is even larger than the summation of the strength of the steel tube and the RC column, which is described as ' 1 (steel tube) +1 (concrete core) greater than 2 (simple summation of the two materials)'. Finally, the authors concluded that, for the CFST column with various column lengths, the Eurocode 4 (BSI, 2004) led to the highest prediction when the slenderness ratio $\lambda$ was less than 80 , whereas the ANSI/AISC360 (ANSI/AISC, 2010) led to the lowest estimate when $\lambda$ was less than 30 .

Concerning the residual stress in cold-formed, thick-walled, square hollow sections, Tong et al. (2012) performed an experimental investigation in sections with thickness greater than $6 \mathrm{~mm}$. Square hollow sections were formed using two different forming processes: (a) a 'direct square' where the section was formed by rolling an annealed flat strip directly into a square hollow section, which was then welded at the edges; (b) 'indirect way from circular to square' where the section was formed by rolling an annealed flat strip into a 
circular hollow section first, which was then welded at the edges and the process was completed by further rolling into a square hollow section. The authors reported that the longitudinal residual stresses were in tension at the outer surface and in compression at the inner surface, with non-linear distributions, which resemble a 'sine' curve along the section thickness.

Dundu (2016) tested 29 square composite columns made of hot-rolled square hollow sections, with variable length and cross-sections ranging from $60 \times 60 \times 3.0 \mathrm{~mm}$ to $150 \times 150 \times 4.5 \mathrm{~mm}$. The concrete strength was $30 \mathrm{MPa}$ for all the specimens and the yield strength of the steel profiles varied from $355 \mathrm{MPa}$ to $522 \mathrm{MPa}$ according to the tensile tests. The test procedure was to apply an axial load at a rate of $2 \mathrm{~mm} / \mathrm{min}$ until failure, using a boundary condition with pinned ends. The general failure mode shows an overall member buckling, caused especially by the large slenderness ratio. As expected, all the specimens showed a reduction in strength as the slenderness ratio increased. The Eurocode 4 (BSI, 2004) predicted a more accurate compressive resistance than the South African design code SANS 10162-1 (SANS, 2001), which overestimated the columns' capacity. The author concluded that square concrete-filled steel tubes provide an insignificant concrete core confinement effect.

Based on this scenario, the present paper presents the results of experiments performed to study the structural response of composite columns made with seam-welded rectangular hollow profiles. The experiments involved columns with: only steel sections (S), concrete-filled (S\&C) and concrete-filled with additional reinforcing bars (S\&RC). The objective of the tests was to identify the contribution of each component to the overall structural response while enabling an assessment of the design recommendations given in Eurocode 4 (BSI, 2004). The outcomes of the present investigation is centred on establishing less conservative buckling curves for the investigated composite columns made of seam-welded rectangular hollow sections produced by a high-frequency induction welding process.

\section{Steel and composite column design}

The structural columns are predominantly loaded by axial compression or by axial compression and bending moment. According to Eurocode 4 (BSI, 2004), distinct composite cross-sections may be considered: steel sections fully encased with concrete; steel sections partially encased with concrete; or steel square, rectangular and circular tube sections filled with concrete.

According to Eurocode 4 (BSI, 2004), the interaction between the two materials (steel and concrete) in composite sections only occurs if the strains for both steel yield stress and concrete compressive stress are similar. It is well known that the strain for the concrete compressive ultimate strength of $3 \cdot 5 \%$ is about two times higher than the strain for the yield stress $(1.75 \%$ ) for the usual steel grades. Thus, for composite action the steel must have the capacity to reach plastic strains, without local buckling, that is, class 1 or 2 sections are required (CEN, 2003b). The composite columns' structural behaviour can be affected by: creep, shrinkage, concrete adherence and confinement, the concrete strength, the slenderness of the composite column cross-section, the steel profile to total cross-sectional area ratio, among others.

The buckling curves of Eurocode 3 (BSI, 2005) and Eurocode 4 (BSI, 2004) distinguish between profiles of hotrolled (curve a) and cold-formed (curve c) sections. However, with current manufacturing processes, seam-welded tubes are manufactured by a high-frequency welding process, which gives them mechanical properties similar to seamless hot-rolled sections.

The investigated composite columns were designed according to Eurocode 4 (BSI, 2004). The steel profiles used in the tests were seam-welded rectangular hollow sections made of ASTM A36 steel grades (equivalent to the steel grades between S235 and S275) and a $30 \mathrm{MPa}$ concrete strength. The Eurocode 4 presents two design methods, the general method and the simplified method; the latter was used in this paper. This method limits the normalised slenderness maximum value to $\lambda \leq 2 \cdot 0$.

According to Eurocode 4 (BSI, 2004), a full interaction of concrete, steel profile and reinforcement bars is the aim. Both reinforcement bars and steel profile cross-sections must reach the yield stress design value $\left(f_{\mathrm{yd}}\right.$ and $\left.f_{\mathrm{sd}}\right)$, and the concrete cross-section must reach the compressive stress design value $\left(0 \cdot 85 f_{\text {cd }}\right)$. Thus, the compressive plastic resistance $N_{\mathrm{pl}, \mathrm{Rd}}$ is

1. $N_{\mathrm{pl}, \mathrm{Rd}}=A_{\mathrm{a}} f_{\mathrm{yd}}+0 \cdot 85 A_{\mathrm{c}} f_{\mathrm{cd}}+A_{\mathrm{s}} f_{\mathrm{sd}}$

In the case of the cross-sections of steel hollow profile filled with concrete, Eurocode 4 (BSI, 2004) specifies that the concrete compressive failure stress should be increased from 0.85 up to $1.0\left(f_{\text {cd }}\right)$ due to the concrete confinement effect. Therefore, the compressive plastic resistance $N_{\mathrm{pl}, \mathrm{Rd}}$ can be rewritten as

2. $N_{\mathrm{pl}, \mathrm{Rd}}=A_{\mathrm{a}} f_{\mathrm{yd}}+A_{\mathrm{c}} f_{\mathrm{cd}}+A_{\mathrm{s}} f_{\mathrm{sd}}$

\section{Experimental programme}

In total, 12 tests were performed in this work, divided into three distinct groups: the first included only the $100 \mathrm{~mm} \times$ $80 \mathrm{~mm} \times 6.3 \mathrm{~mm}$ seam-welded steel profiles $(\mathrm{S})$. The second incorporated the same steel profiles now filled with concrete (S\&C). The last group was also filled with concrete (S\&RC), 
Table 1. Experiments and Eurocode 4 design predictions comparison

\begin{tabular}{|c|c|c|c|c|c|}
\hline Test & $N_{\text {exp }}: \mathrm{kN}$ & $N_{\mathrm{pl}, \mathrm{Rd}}: \mathrm{kN}$ & $N_{\mathrm{b}, \mathrm{Rd}}: \mathrm{kN}$ & $N_{\mathrm{EC} 4}: \mathrm{kN}$ & $N_{\text {exp }} / N_{\mathrm{EC} 4}$ \\
\hline TR-03_1000_S & $962 \cdot 34$ & $805 \cdot 73$ & $642 \cdot 82$ & $642 \cdot 82$ & 1.50 \\
\hline TR-04_1000_S & 839.08 & $805 \cdot 73$ & $642 \cdot 82$ & $642 \cdot 82$ & $1 \cdot 31$ \\
\hline TR-01_1000_S\&C & $885 \cdot 13$ & $958 \cdot 30$ & $822 \cdot 90$ & $822 \cdot 90$ & 1.08 \\
\hline TR-06_1000_S\&C & $1059 \cdot 60$ & $958 \cdot 30$ & $822 \cdot 90$ & $822 \cdot 90$ & 1.29 \\
\hline TR-02_1000_S\&RC & $936 \cdot 17$ & $1020 \cdot 64$ & $869 \cdot 76$ & $869 \cdot 76$ & 1.08 \\
\hline TR-05_1000_S\&RC & $994 \cdot 84$ & $1020 \cdot 64$ & $869 \cdot 76$ & $869 \cdot 76$ & $1 \cdot 14$ \\
\hline TR-07_500_S & $1032 \cdot 41$ & $805 \cdot 73$ & - & $805 \cdot 73$ & $1 \cdot 28$ \\
\hline TR-09_500_S & $1022 \cdot 36$ & $805 \cdot 73$ & - & $805 \cdot 73$ & $1 \cdot 27$ \\
\hline TR-08_500_S\&C & $1125 \cdot 69$ & $958 \cdot 30$ & - & $958 \cdot 30$ & $1 \cdot 17$ \\
\hline TR-10_500_S\&C & $1178 \cdot 59$ & $958 \cdot 30$ & - & $958 \cdot 30$ & $1 \cdot 23$ \\
\hline TR-11_500_S\&RC & $1271 \cdot 72$ & $1020 \cdot 64$ & - & $1020 \cdot 64$ & 1.25 \\
\hline TR-12_500_S\&RC & $1310 \cdot 79$ & $1020 \cdot 64$ & - & $1020 \cdot 64$ & $1 \cdot 28$ \\
\hline Mean & & & & & $1 \cdot 24$ \\
\hline Standard deviation & & & & & 0.11 \\
\hline
\end{tabular}

while presenting four $6.3 \mathrm{~mm}$ dia. longitudinal steel reinforcing bars and stirrups of the same diameter (only present at the supports and mid-span to tie up the reinforced bars).

The other variable investigated in the experiments was the column height, that is, two column heights were tested at $1000 \mathrm{~mm}$ and $500 \mathrm{~mm}$, as can be observed in Table 1. Their associated normalised slenderness $\bar{\lambda}$ indicated that, for the $1000 \mathrm{~mm}$ composite columns $(\bar{\lambda} \approx 0.60)$, the flexural global buckling controlled the column design, whereas for the $500 \mathrm{~mm}$ composite columns $(\bar{\lambda} \approx 0 \cdot 20)$, the failure was associated with the full section yielding.

In relation to the necessary concrete amount to fill the prototypes, the compression specimen tests and the concrete compressive strength to be reached, the mass proportion was as follows: 1: $2 \cdot 17: 2 \cdot 44(28 \cdot 11 \mathrm{~kg}$ of cement, $61 \cdot 00 \mathrm{~kg}$ of fine aggregate, $68.59 \mathrm{~kg}$ of coarse aggregate, $15.46 \mathrm{~kg}$ of water and $0.028 \mathrm{~kg}$ of superplasticiser) and a water-cement factor of 0.55 were utilised. The stress plotted against strain curves obtained according to the Brazilian standard NBR 8522 (ABNT, 2008) made possible the determination of the concrete secant elastic modulus, $E_{\mathrm{cm}}=24 \cdot 16 \mathrm{GPa}$. Compression specimen tests led to a concrete compressive strength, $f_{\mathrm{ck}}=26 \cdot 42 \mathrm{MPa}$. This compressive strength was less than the pre-defined value of $30 \mathrm{MPa}$, probably due to the superplasticiser addition and/or by the non-reduction of the water-cement factor during the concrete casting.

The steel A36 hollow profiles' mechanical characterisation was made according to NBR 6152 (ABNT, 2002). Five coupon tests were performed leading to: a mean Young's modulus of 193.52 GPa with a standard deviation of $12.02 \mathrm{MPa}$; a mean yield stress of $382 \cdot 17 \cdot 52 \mathrm{MPa}$ with a standard deviation of $5.04 \mathrm{MPa}$; and a mean ultimate stress of $441.03 \mathrm{MPa}$ with a standard deviation of $2.89 \mathrm{MPa}$. Additional details can be found in Castanheira (2016).
Special plates with slots in which cylinders were inserted were fabricated and adopted at the column ends to simulate simple support conditions, close to $k=1 \cdot 0$, and increase the columns' buckling effective length as presented in Figure 1. This strategy was used in the profile lower inertia direction to induce the flexural buckling to occur in this direction. Figure 2 shows the columns assembly in the hydraulic press during the tests, with the linear variable displacement transducers (LVDTs) positioned at eight different points. Figure 2 also depicts the strain gauges ( $\mathrm{S}$ ) that were adopted and used to determine the maximum strains achieved at four different points along the column.

\section{Experimental results}

The $500 \mathrm{~mm}$ columns tests (stub columns) were simpler, as there was no need to simulate the simple support conditions because the full section yield was expected. Alternatively, the $1000 \mathrm{~mm}$ high columns (intermediate columns) test assembly was more complex due to the hinge simulation arrangement to simulate the column flexural buckling response. Table 1 shows the ratio between the tests' maximum loads and the values predicted by Eurocode 4 (BSI, 2004) evaluated according to the material mechanical properties obtained from the specimens. The Eurocode 4 predictions $\left(N_{\mathrm{EC} 4}\right)$ considered the possibilities of full section yielding $\left(N_{\mathrm{pl}, \mathrm{Rd}}\right)$ and flexural buckling $\left(N_{\mathrm{b}, \mathrm{Rd}}\right)$.

Figure 3(a) depicts a comparison between the $500 \mathrm{~mm}$ high column tests to assess the influence of the concrete and additional reinforcing bars. All tests presented the full crosssection yielding and a subsequent local buckling at midheight and/or close to the supports. The steel columns (S) present curves with lower ultimate load values, a steeper load decreasing branch and a smaller ductility capacity. The curves for steel columns with concrete (S\&C) and with reinforced concrete (S\&RC) reach higher ultimate loads; this occurred, among other reasons, owing to the presence 


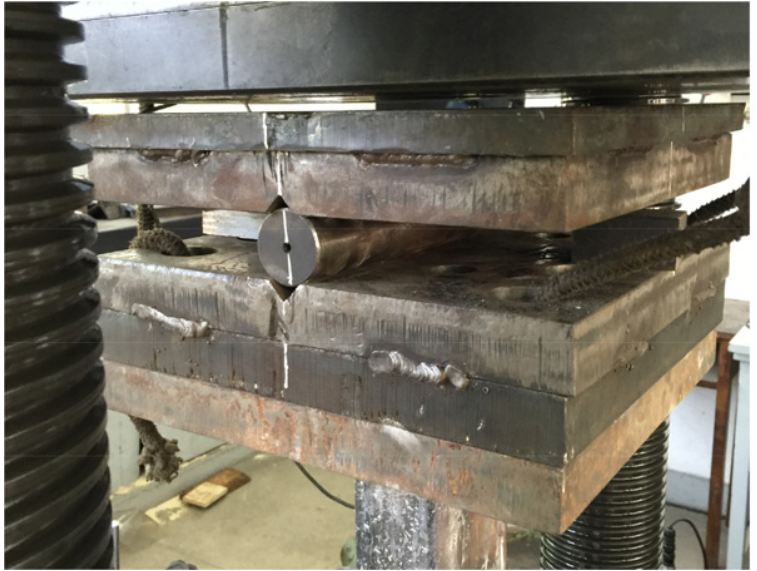

(a)

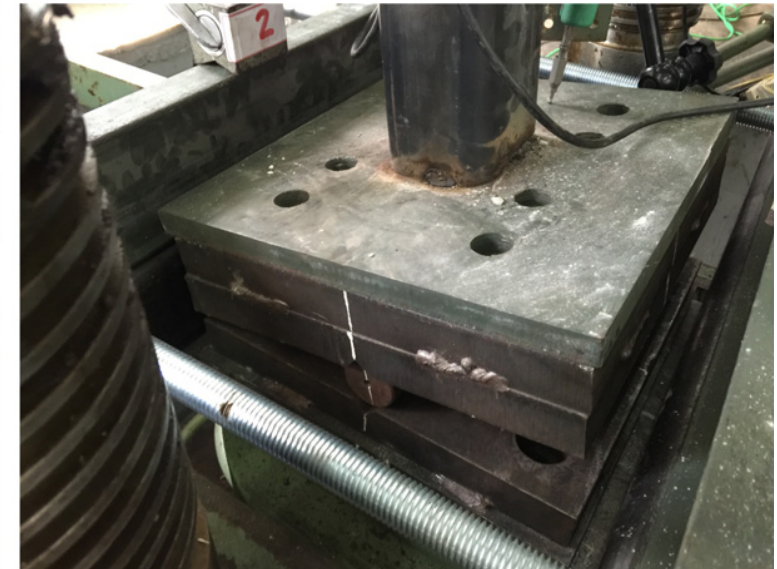

(b)

Figure 1. End conditions with pinned supports: (a) top support, before test; (b) bottom support, maximum rotation at ultimate load

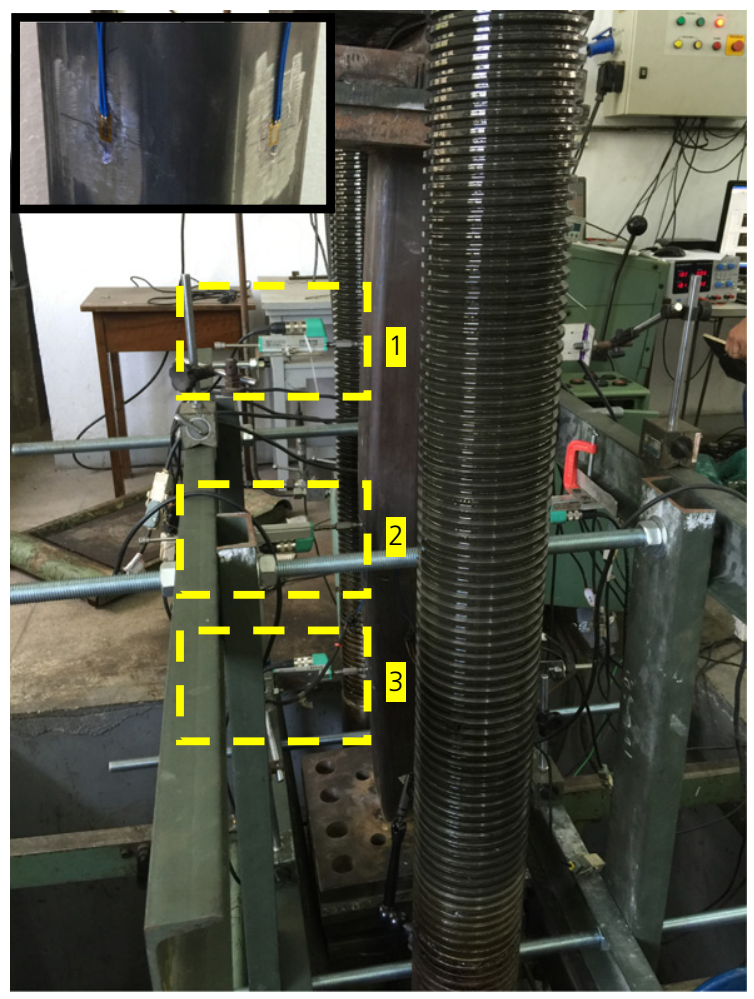

(a)

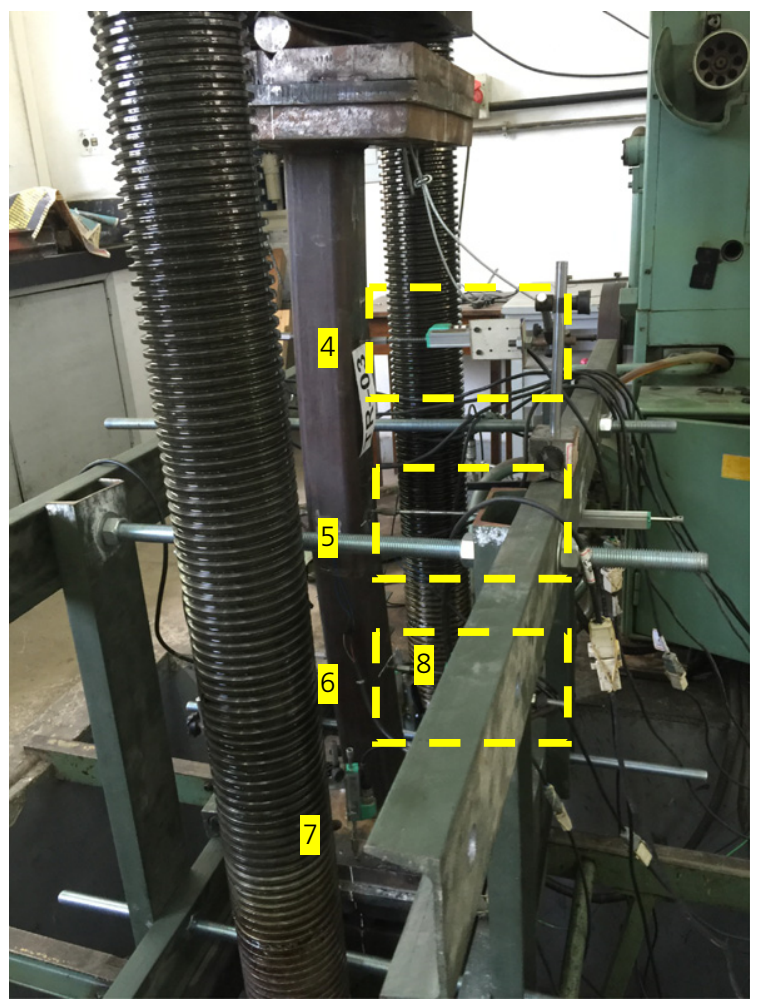

(b)

Figure 2. Test configuration and LVDT layout - TR03_1000_S: (a) rear view; (b) front view

of the concrete and longitudinal reinforcement bars that increase the columns' load-carrying capacities. These curves also presented a gradual load decreasing branch and higher ductility capacities.
Figure 3(b) presents a similar comparison for the $1000 \mathrm{~mm}$ high columns. It can be observed that all the column failures were controlled by flexural buckling, with a well-defined ultimate load followed by an abrupt unloading branch. Once 
Structures and Buildings Volume 171 Issue SB1
Structural assessment of composite seam-welded rectangular hollow columns

Castanheira, de Lima, da Silva Vellasco and da Nóbrega Tavares
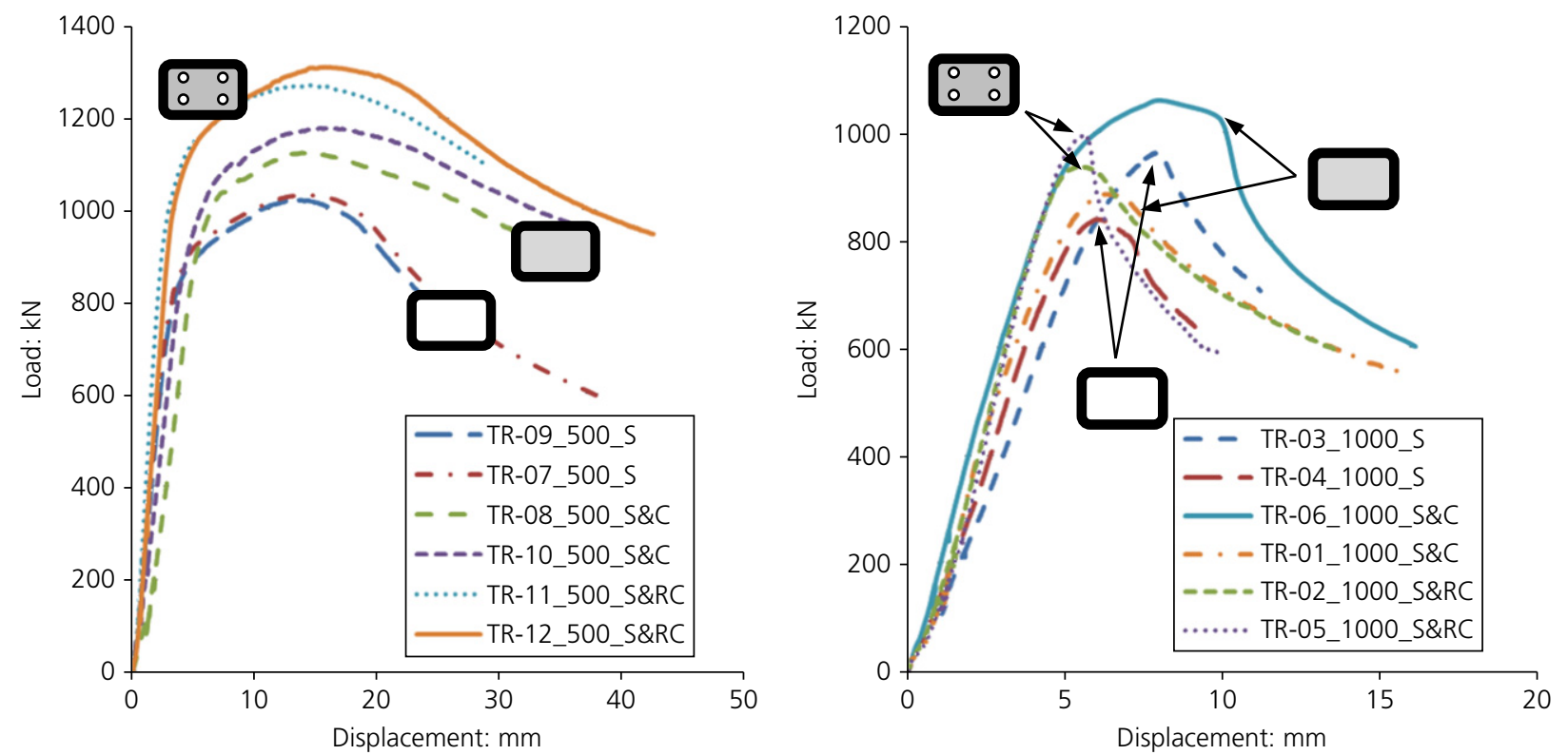

Figure 3. Steel and composite columns load plotted against displacement curves: (a) 500 mm high columns; (b) 1000 mm high columns

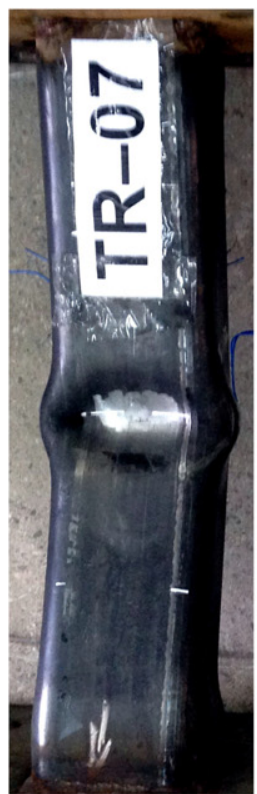

(a)

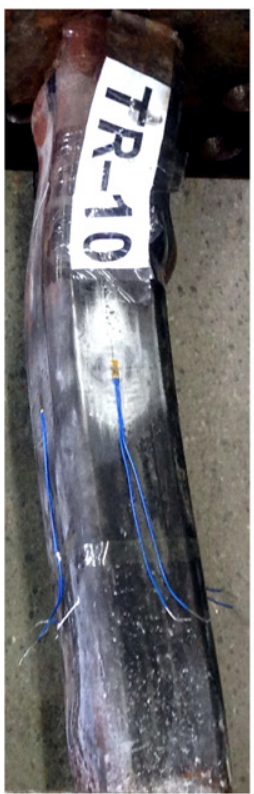

(b)

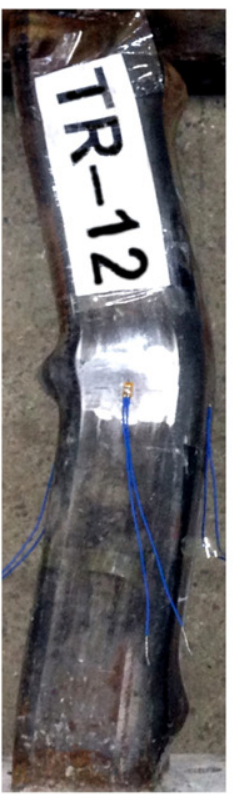

(c)

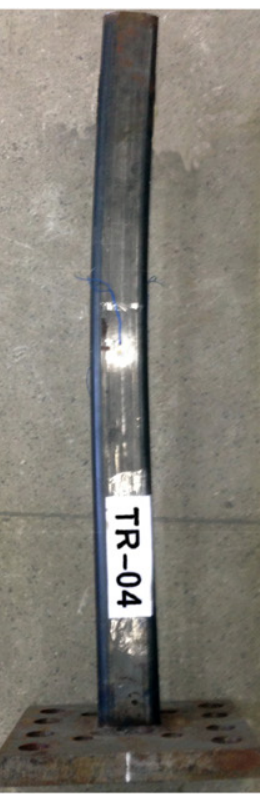

(d)

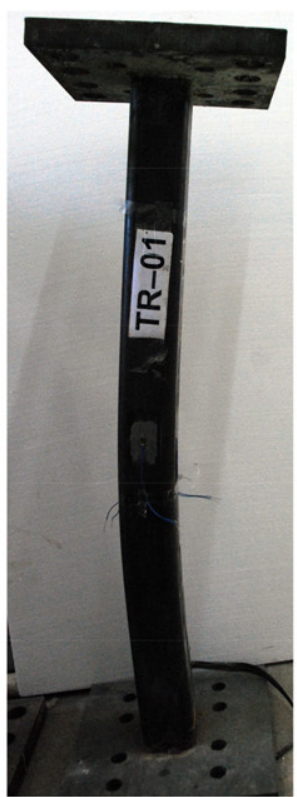

(e)

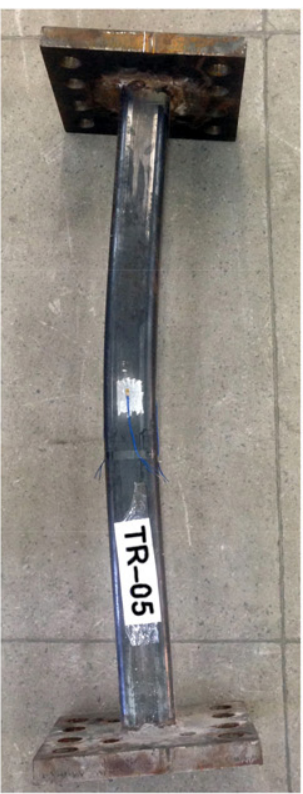

(f)

Figure 4. Columns' deformed configurations: (a) TR-07_500_S; (b) TR-08_500_S\&C; (c) TR-12_500_S\&RC; (d) TR-04_1000_S; (e) TR-01_1000_S\&C; (f) TR-05_1000_S\&RC

more the steel columns (S) presented curves with lower maximum load values, a steeper load decreasing branch and a smaller ductility capacity. The concrete-filled columns (S\&C) and the reinforced composite columns (S\&RC) achieved variable ultimate loads values. One column presented a value almost equal to the steel column and another with a higher value, probably due to the concrete strength and the presence of longitudinal reinforcement bars. These curves also presented a gradual load decreasing branch and higher ductility capacities. An inspection of the curves' initial slope made it 


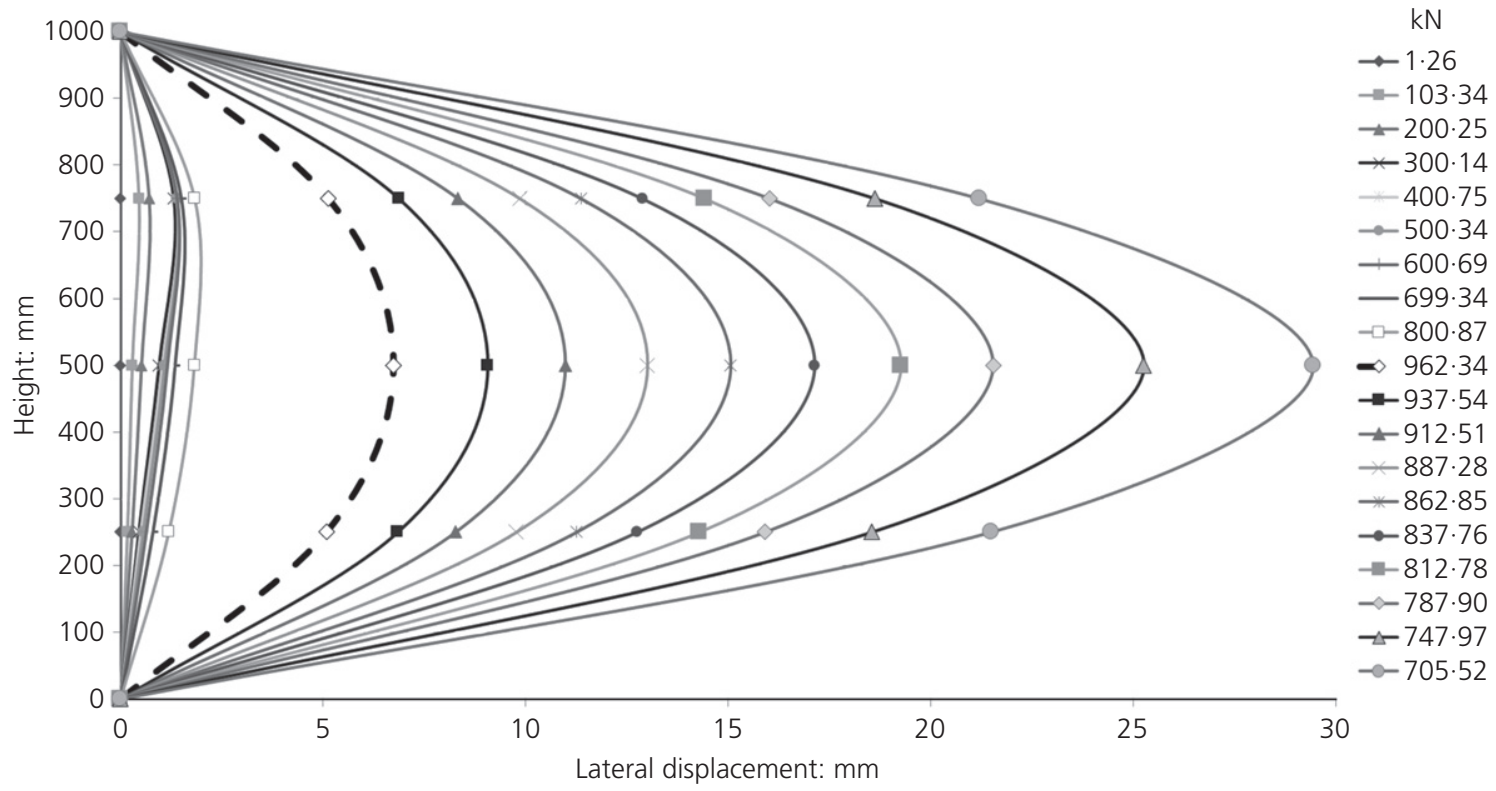

Figure 5. Lateral displacement evolution along the column height, TR-03_1000_S test

possible to conclude that, as expected, for steel columns the initial stiffness is lower than for all the composite steel columns.

Figure 4 illustrates the typical columns' deformed configurations. The $500 \mathrm{~mm}$ columns' deformed shapes presented in Figures 4(a)-4(c) are characterised by the presence of plastic hinges and local buckling (the latter occurred after the full section yielded) at the column centre and supports. The $1000 \mathrm{~mm}$ columns' deformed configurations presented in Figures 4(d)-4(f) are all characterised by a maximum lateral displacement close to the column's centre, due to the flexural buckling that occurred in the column's minor axis.

In order to evaluate the actual boundary conditions that occurred in the tests, the results obtained with the displacement transducers are presented and discussed. Figure 5 illustrates the results of the lateral displacements of three selected points along the column height for various applied load magnitudes. These results were acquired with the aid of six displacement transducers positioned at three points along the column height: $750 \mathrm{~mm}, 500 \mathrm{~mm}$ and $250 \mathrm{~mm}$ measured from the column base. Figure 5 illustrates these curves for the $1.0 \mathrm{~m}$ high non-composite column test TR-03_1000_S. In this figure it is possible to observe that, before the ultimate load $(962.34 \mathrm{kN})$ is reached, the curves exhibit a similar behaviour associated with a column configuration with fixed and hinged supports, that is, $k=0 \cdot 7$. As the load increases, the horizontal displacements change, coming into line with a column with both hinged supports, that is, $k=1 \cdot 0$, while presenting a typical global buckling collapse.
Figure 6 presents the normalised load plotted against normalised slenderness curves for the investigated columns groups (S, S\&C and S\&RC). For each group the Eurocode 3 (BSI, 2005) and Eurocode 4 (BSI, 2004) curves associated with seamless steel profiles (curve a) and seam-welded steel profile (curve c) are presented alongside the test results, making possible an assessment of the actual curve that better fits the tested configurations.

The TR-09_500_S and TR-07_500_S, TR-08_500_S\&C and TR-10_500_S\&C, TR-11_500_S\&RC and TR-12_500_S\&RC tests were all stub columns with normalised slenderness values, $\bar{\lambda}$, less than $0 \cdot 2$, and they were strongly affected by strain hardening. Figure 6(b) presents the results of tests TR-08_500_ S\&C, TR-10_500_S\&C, TR-01_1000_S\&C and TR-06_1000_ S\&C. This figure also incorporates the 29 square composite columns results by Dundu (2016), which were made of hotrolled square hollow sections, with variable length and crosssections ranging from $60 \times 60 \times 3.0 \mathrm{~mm}$ to $150 \times 150 \times$ $4.5 \mathrm{~mm}$. The Dundu (2016) tests adopted in all specimens a concrete strength of $30 \mathrm{MPa}$ and a steel profiles yield strength varying from $355 \mathrm{MPa}$ to $522 \mathrm{MPa}$. It may be observed that the Dundu (2016) tests with normalised slenderness ranging from 0.6 and 1.5 overestimated composite columns' resistances predicted by Eurocode 4 curve a.

The TR-03_1000_S and TR-04_1000_S, TR-01_1000_S\&C and TR-06_1000_S\&C, TR-02_1000_S\&RC and TR-05_1000_ S\&RC tests can be classified as simple supported intermediate columns with height of $1000 \mathrm{~mm}$, that is, $k=1$, controlled by flexural buckling, where the normalised slenderness ratios are 


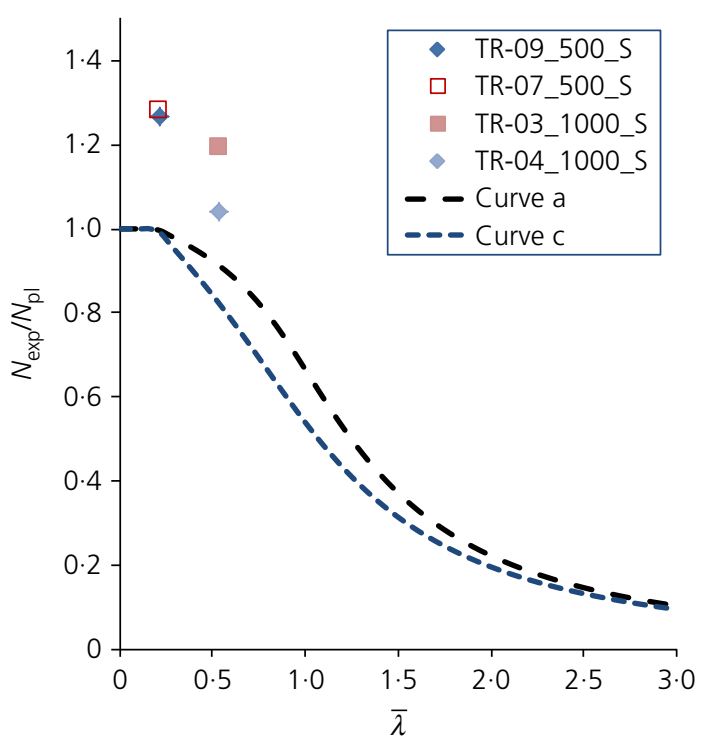

(a)

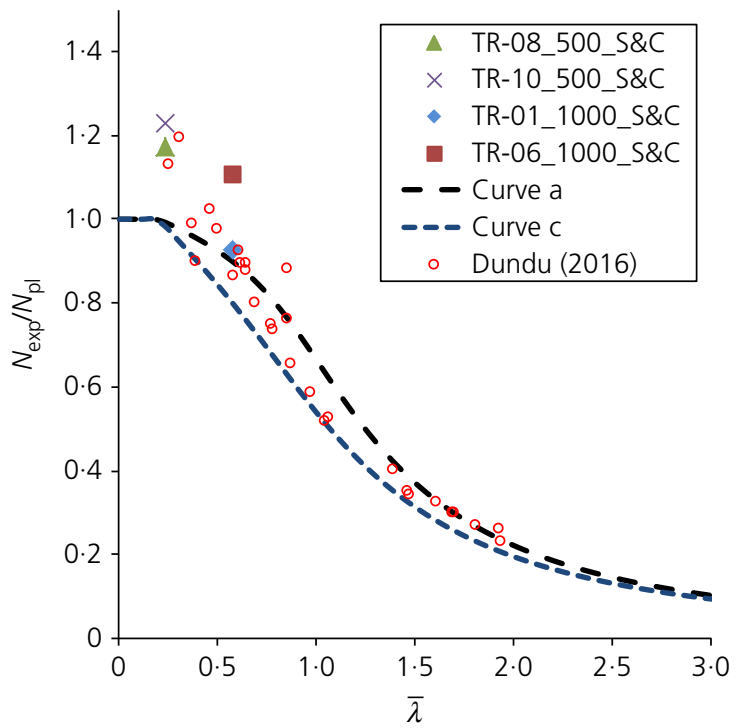

(b)

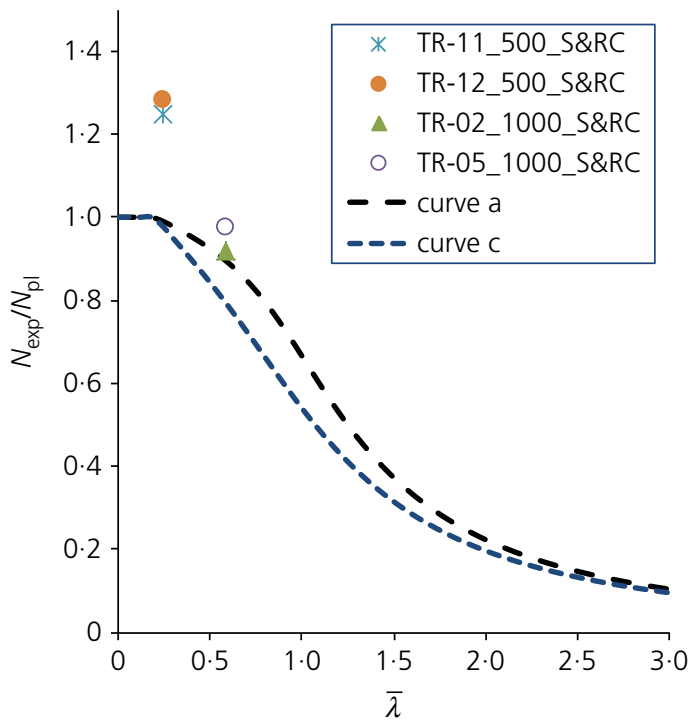

(c)

Figure 6. Normalised column load plotted against normalised slenderness curves for: (a) steel columns; (b) steel and concrete columns; (c) steel and reinforced-concrete columns

calculated taking into account the materials involved (steel, concrete and reinforcement bars). All tested columns with normalised slenderness ratios ranging from 0.2 and 0.6 are situated above Eurocode 4 (BSI, 2004) curve a. This affirmative was also observed in the tests performed by Dundu (2016). This strongly indicates that the conservatism is associated with the design of these seam-welded profiles in this normalised slenderness range, when, in fact, they could be designed as seamless profiles. Obviously, more tests must be performed with other cross-sections and other normalised slenderness, especially in the $0.6-1.5$ range, to fully validate such an affirmation.

\section{Final considerations}

Table 2 shows the comparison of the gain in percentage associated with each composite column material. Equations are also presented taking into account the percentage associated with each resistance contribution, for both experiments and Eurocode 4 (CEN, 2004) design values. The results shown in this table enable the determination of the individual contributions of the steel profile (S), concrete ( $\mathrm{S} \& \mathrm{C}$ minus $\mathrm{S}$ ) and reinforcing bars (S\&RC minus $\mathrm{S} \& \mathrm{C}$ ) assessed from the experiments and Eurocode 4 predictions. The experiments and Eurocode 4 predictions indicated that the steel contribution was responsible for $80 \%$ of the column 
Table 2. Assessment of the individual contributions to the column load-carrying capacity

\begin{tabular}{|c|c|c|c|}
\hline \multicolumn{3}{|c|}{ Mean experimental resistances: $\mathrm{kN}$} & \multirow{2}{*}{$\begin{array}{c}\% \text { total } \\
80.0\end{array}$} \\
\hline Steel & $S=$ & $1027 \cdot 39$ & \\
\hline Concrete & $S \& C-S=$ & $124 \cdot 76$ & $9 \cdot 0$ \\
\hline Reinforcing bars & $S \& R C-S \& C=$ & $139 \cdot 12$ & $11 \cdot 0$ \\
\hline Total & $S+S \& C+S \& R C=$ & $1291 \cdot 26$ & $100 \cdot 0$ \\
\hline \multicolumn{4}{|c|}{ Eurocode 4 predictions: kN } \\
\hline Steel & $S=$ & $805 \cdot 73$ & $79 \cdot 0$ \\
\hline Concrete & $S \& C-S=$ & $152 \cdot 57$ & $15 \cdot 0$ \\
\hline Reinforcing bars & $S \& R C-S \& C=$ & $62 \cdot 34$ & $6 \cdot 0$ \\
\hline Total & $S+S \& C+S \& R C=$ & $1020 \cdot 64$ & $100 \cdot 0$ \\
\hline
\end{tabular}

load-carrying capacity. This was not the case for the other two components. The experiments and Eurocode 4 predictions for the concrete contribution to the column capacity were, respectively, $9 \%$ and $15 \%$, whereas for the reinforcing bar contribution to the column capacity they were, respectively, $11 \%$ and $6 \%$.

The tests with columns $1000 \mathrm{~mm}$ high (intermediate slenderness) were controlled by flexural buckling, while the columns $0.5 \mathrm{~m}$ high (stub columns) failed by the section yielding followed by local buckling at the column centre and near its supports. The results obtained from the lateral displacement transducers indicated that the hinged support configuration performed as expected, while the effect of possible eccentricities created during each test installation and profile initial imperfections have not led to any discrepancies in the results.

The load plotted against vertical displacement curves indicated a real resistance increase in all composite columns in relation to the non-composite (only steel tubes) columns. It could be observed that the columns controlled by section yielding were associated with curves that had less defined ultimate loads, while also presenting higher ductility capacities. It could also be noted that, in all of the $1000 \mathrm{~mm}$ high columns, the failure modes presented a well-defined ultimate load followed by an abrupt unloading branch. An inspection of the curves' initial slope made it possible to conclude that, as expected, for steel columns the initial stiffness is lower than for all the composite steel columns.

Unfortunately, according to the authors' knowledge, there are still very few references dealing with seam-welded profiles. However, all tested columns with seam-welded profiles and normalised slenderness ranging from 0.2 to 0.6 indicated the conservatism of Eurocode 4 (BSI, 2004) curve a. This is a strong indication of the under-design of these seam-welded profiles and that they could be designed as seamless profiles. Obviously, more tests must be performed with other crosssections and other normalised slenderness values, especially in the $0 \cdot 6-1 \cdot 5$ range, to fully validate these results.

\section{Acknowledgements}

The authors would like to thank FAPERJ, CAPES and CNPq for the financial support provided for the present investigation. The authors would also like to express their gratitude to UERJ and TUPER ${ }^{\circledR}$, who provided the material used in the experiments.

\section{REFERENCES}

ABNT (2002) (Brazilian Association of Technical Standards) NBR 6152: Metallic materials - tensile testing at room temperature. ABNT, Rio de Janeiro, Brazil (in Portuguese).

ABNT (2008) (Brazilian Association of Technical Standards) NBR 8522: Concrete - compression elasticity static modulus determination. ABNT, Rio de Janeiro, Brazil (in Portuguese).

AIJ (Architectural Institute of Japan) (1997) Recommendations for Design and Construction of Concrete Filled Steel Tubular Structures. AIJ, Tokyo, Japan.

ANSI/AISC (2010) ANSI/AISC 360-10: Specification for structural steel buildings. American Institute of Steel Construction (AISC), Chicago, IL, USA.

Calado L and Santos J (2013) Composite Structures of Steel and Concrete, 2nd edn. IST Press, Lisbon, Portugal.

CAN/CSA (2001) CAN/CSA S16-01:2001: Limit states design of steel structures. Canadian Standards Association, Ontario, Canada.

Castanheira DS (2016) Assessment of Tubular Steel Columns Fullfilled with Concrete. MSc dissertation, PGECIV Post-Graduate Program in Civil Engineering, UERJ - State University of Rio de Janeiro, Rio de Janeiro, Brazil (in Portuguese).

BSI (2004) BS EN 1994-1-1: Eurocode 4: Design of composite steel and concrete structures, Part 1.1 General rules and rules for buildings. BSI, London, UK.

BSI (2005) BS EN 1993-1-1: Eurocode 3: Design of steel structures, Part 1.1 General rules and rules for buildings. BSI, London, UK.

Dundu M (2016) Column buckling tests of hot-rolled concrete filled square hollow sections of mild to high strength steel. Engineering Structures 127: 73-85, http://dx.doi.org/10.1016/j.engstruct.2016. 08.039.

Han L, Liu W and Yang Y (2008) Behaviour of concrete-filled steel tubular stub columns subjected to axially local compression. Journal of Constructional Steel Research 64(4): 377-387.

Han LH (2002) Tests on stub columns of concrete-filled RHS sections. Journal of Constructional Steel Research 58(3): 353-372.

Han LH, Li W and Bjorhovde R (2014) Developments and advanced applications of concrete-filled steel tubular (CFST) structures: members. Journal of Constructional Steel Research 100: 211-228, https://doi.org/10.1016/j.jcsr.2014.04.016.

Nardin S (1999) Theoretical-Experimental Study of Composite Columns Composed by Hollow Steel Profiles Filled with High-strength Concrete. Dissertation (Master's degree in Civil Engineering), Engineering School of São Carlos, University of São Paulo, São Carlos, Brazil, 148 f.

Nardin S and El Debs AL (2007) Axial load behaviour of concrete-filled steel tubular columns. Proceedings of the Institution of Civil Engineers - Structures and Buildings 160(1): 13-22, http://dx.doi.org/10.1680/stbu.2007. 160.1.13, http://dx.doi.org/10.1680/stbu.2007.160.1.13.

Oliveira WL, Nardin S, El Debs AL and El Debs M (2009) Influence of concrete strength and length/diameter on the axial capacity 
of CFT columns. Journal of Constructional Steel Research 65(12): 2103-2110.

Sakino K, Nakahara H, Morino S and Nishiyama I (2004) Behaviour of centrally loaded concrete-filled steel-tube short columns. Journal of Structural Engineering 130(2): 180-188.

SANS (South Africa National Standards) (2001) SANS 10162-1: The structural use of steel: part 1 - limit-state design of hot-rolled steelwork. SANS, Pretoria, South Africa.

Schneider S (1998) Axially loaded concrete-filled steel tubes. Journal of Structural Engineering 124(10): 1125-1138.
Silva AT, D'Aniello M, Rebelo C et al. (2016) High strength steel in chevron concentrically braced frames designed according to Eurocode 8. Engineering Structures 124: 167-185.

Tenchini A, D'Aniello M, Rebelo C et al. (2014) Seismic performance of dual-steel moment resisting frames. Journal of Constructional Steel Research 101: 437-454.

Tong L, Hou G, Chen Y et al. (2012) Experimental investigation on longitudinal residual stresses for cold-formed thick-walled square hollow sections. Journal of Constructional Steel Research 73: 105-116, http://dx.doi.org/10.1016/j.jcsr.2012.02.004.

\section{How can you contribute?}

To discuss this paper, please email up to 500 words to the editor at journals@ice.org.uk. Your contribution will be forwarded to the author(s) for a reply and, if considered appropriate by the editorial board, it will be published as discussion in a future issue of the journal.

Proceedings journals rely entirely on contributions from the civil engineering profession (and allied disciplines). Information about how to submit your paper online is available at www.icevirtuallibrary.com/page/authors, where you will also find detailed author guidelines. 